VERTAISARVIOITU

KOLLEGIALT GRANSKAD

PEER-REVIEWED

www.tsv.fi/tunnus

\title{
TOIMIJUUS JA VUOROVAIKUTUSJÄRJESTYS AMERIKKALAISTEN SUOMENOPPIJOIDEN ITSENÄISESSÄ KIELENKÄYTÖSSÄ
}

\author{
Elisa Räsänen, Indiana University \& Jyväskylän yliopisto
}

\begin{abstract}
Aiemmat tutkimukset ovat osoittaneet vastakkainasettelun luokassa ja luokan ulkopuolella tapahtuvassa kielenkäytössä ja oppimisessa. Tässä artikkelissa tarkastelen neljää amerikkalaista suomenoppijaa ja sitä, miten he hakeutuvat aktiivisina toimijoina itsenäisiin suomen kielen käyttötilanteisiin. Artikkelin aineistona on portfoliotehtävä, jossa oppijat ovat dokumentoineet ja reflektoineet itsenäistä, luokkahuoneen ulkopuolella tapahtuvaa kielenkäyttöään. Tarkastelen aineistoa Scollonin ja Scollonin (2004) neksusanalyysia ja van Lierin (2010) ekologista viitekehystä hyödyntäen. Artikkelin analyysimenetelmänä on diskurssianalyysi. Portfolioissa dokumentoidut vuorovaikutustilanteet rakentuivat hierarkkisesti, mikä usein syntyi oppijan pyrkimyksestä saada vuorovaikutuskumppanista ja -tilanteesta maksimaalinen hyöty ja kielellinen altistus. Lisäksi hierarkkisuutta loivat oppijan ja asiantuntevan suomenpuhujan erilaisiksi koetut roolit. Vuorovaikutus rakentuikin usein oppijan aloitteen ja asiantuntevan kielenkäyttäjän vastausten varaan. Tämä artikkeli osoittaa, kuinka suuri merkitys aloitteellisuudella, toimintaympäristöllä ja vuorovaikutuskumppaneilla on vieraan kielen oppijoiden itsenäisessä kielenkäytössä. Tutkimustuloksia voi hyödyntää vieraan kielen pedagogiikan kehittämiseen, jotta se vastaisi paremmin oppijoiden todellisia kielenkäyttötarpeita.
\end{abstract}

Avainsanat: affordanssit, diskurssianalyysi, neksusanalyysi, sosiaalinen media, toimijuus, vieraan kielen oppiminen, vuorovaikutusjärjestys

\section{JOHDANTO}

Jo vieraan kielen alkeita opiskelevilla voi olla erilaisia kohdekielisiä verkostoja tai kiinnostusta niiden rakentamiseen omassa toimintaympäristössään. Teknologian ja ihmisten lisääntyneen liikkuvuuden myötä erilaiset kohdekieliset ympäristöt ovat helposti saavutettavissa, kunhan oppija on aktiivinen: internetissä oppijat pääsevät käyttämään suomea suomenkielisessä ympäristössä milloin vain riippumatta maantieteellisestä etäisyydestä
(Vaarala \& Jalkanen, 2011). Lisäksi globaali todellisuus ja ihmisten lisääntynyt liikkuvuus kyseenalaistavat koko vieraan kielen käsitteen (Kramsch, 2014).

Aiemmat tutkimukset ovat käsitelleet vastakkainasettelua luokassa ja luokan ulkopuolella tapahtuvassa kielenkäytössä ja -oppimisessa (Dufva, Heikkilä \& Martin, 2003; peruskouluista Luukka, ym., 2008). Pedagogisissa keskusteluissa on pohdittu, miten toi-

\footnotetext{
Kirjoittajan yhteystiedot:

Elisa Räsänen

elisa.k.rasanen@student.jyu.fi
} 
sen kielen opetuksen sisältöaines tulisi valita ja kuka on vastuussa oppimisesta (esim. Aalto, Mustonen \& Tukia, 2009). Pohdin samoja kysymyksiä vieraan kielen oppimisen kontekstissa. Tarkastelen tässä artikkelissa neljää amerikkalaista eri tasokursseilla opiskelevaa suomen kielen opiskelijaa, Owenia, Ivya, Tinaa ja Veraa, sekä heidän itsenäistä kielenkäyttöään Scollonin ja Scollonin (2004) neksusanalyysia ja van Lierin (2010) ekologista viitekehystä hyödyntäen. Tarkastelen sitä, miten oppijat hakeutuvat aktiivisina toimijoina suomen kielen käyttötilanteisiin hyödyntäen oppimisympäristönsä ja teknologian mahdollistamia tarjoumia (affordance; ks. van Lier, 2000). Olen kiinnostunut erityisesti vuorovaikutusjärjestyksestä (interaction order; Goffman, 1983; Scollon \& Scollon, 2004) eli siitä, miten oppijoiden itsenäisen kielenkäytön tilanteet ovat rakentuneet sosiaalisesti ja hierarkkisesti. Toimijuudella tarkoitan tässä yksilön kirjaimellista tai metaforista liikettä, suuntautumista tai suunnan muutosta (movement; van Lier, 2010). Toimijuutta on lisäksi yksilön yleinen ja tilanteinen tunne oman toiminnan vaikuttavuudesta sekä käytös eli se, miten hän toimintaan osallistuu (Mercer, 2011). Oppiminen riippuu yksilön toimijuudesta. Kehittyäkseen elinikäiseksi oppijaksi, oppijan täytyy hyödyntää toimijuuttaan itseohjautuvasti (van Lier, 2010).

Gibson (1979, s. 79) on kehittänyt käsitteen affordanssi (tarjouma, affordance) kuvaamaan sitä, mitä mahdollisuuksia ympäristö tarjoaa yksilölle - esimerkiksi sillan voi ylittää tai järvessä voi uida. Tarjouma viittaa Gibsonin alkuperäisessä määritelmässä eliön vastavuoroiseen suhteeseen toimintaympäristönsä tietyn ominaisuuden kanssa. Tarjouma ei ole siis toimijan tai sen kohteen ominaisuus vaan näiden välinen suhde. Se mahdollistaa tietynlaisen toiminnan, mutta ei aiheuta sitä. (van Lier, 2000.) Kielenoppijat, nekin, jotka näennäisesti elävät samanlaisessa ympäristössä, voivat havaita asioita eri tavoilla. (Menezes, 2011, s. 61). Jos kielenoppija on aktiivinen ja sitoutunut, hän havaitsee kielellisiä mahdollisuuksia ja voi käyttää niitä kielelliseen toimintaan (van Lier, 2000). Tutkimuksessani tarkoitan tarjoumilla oppimisympäristön ja teknologian mahdollistamia vuorovaikutustilanteita ja kielenkäyttömahdollisuuksia, joita oppija voi aktiivisesti hyödyntää tai jättää hyödyntämättä. Tarjoumia voidaan ajatella sosiaalisina toimintoina (Menezes, 2011, s. 61). Hahmotamme maailmaa ja sen tarjoumia suhteessa itseemme ja identiteettiimme. Vuorovaikutustilanteen osapuolet rakentavat identiteettiään sosiaalisessa vuorovaikutuksessa ja ottavat itselleen erilaisia tilanteisia rooleja (Bucholtz \& Hall, 2010, s. 18-20). Roolien myötä vuorovaikutusta myös rakennetaan hierarkkisesti.

Portfoliotehtävässä suomenoppijat ovat dokumentoineet ja analysoineet itsenäistä, luokkahuoneen ulkopuolella tapahtuvaa kielenkäyttöään. Tutkimuksen osallistujat opiskelevat suomea Suomesta maantieteellisesti etäisessä yhdysvaltalaisessa suomen kielen ja kulttuurin opetusohjelmassa, joka on myös kaukana suomea kohdekielenä puhuvista yhteisöistä, koska alueelle ei ole historiallisesti muuttanut merkittäviä määriä suomalaisia. He kuitenkin käyttävät suomea monipuolisesti erilaisissa vuorovaikutustilanteissa sekä teknologiavälitteisesti että fyysisessä toimintaympäristössään.

Tutkimuksessa on yhtymäkohtia arjessa oppimisen tutkimukseen (learning in the wild: Lilja \& Piirainen-Marsh, 2018; Wagner, 2015), jossa on tutkittu esimerkiksi luokan ulkopuolista kielenkäyttöä ja sitä, miten kohdekielisiä asiakaspalvelutilanteita tarkastellaan yhdessä kielikurssilla. Tässä artikkelissa pääpaino on kuitenkin itsenäisissä ei-institutionaalisissa suomen kielen käyttötilanteissa. Vieraan kielen oppijoiden itsenäisessä ei-institutionaalisessa kielenkäytössä on 
aiemmin tarkasteltu esimerkiksi affekteja ja strategioita (Hurd, 2008). Lisäksi on tutkittu esimerkiksi pelien (Piirainen-Marsh \& Tainio, 2007) ja mobiilisovellusten käyttöä (Kukulska-Hulme, 2012). Tämä artikkeli jatkaa näitä näkökulmia keskittyen kartoittamaan vieraan kielen oppijoiden kohdekielisiä sosiaalisia toimintoja ja sitä, miten oppijat näitä kokemuksia merkityksellistävät. Vastaan siis artikkelissa seuraaviin kysymyksiin: Miten oppijat hakeutuvat aktiivisina toimijoina suomen kielen käyttötilanteisiin hyödyntäen oppimisympäristönsä ja teknologian mahdollistamia tarjoumia? Miten vuorovaikutusjärjestys näissä tilanteissa rakentuu?

Luvussa 2 esittelen tutkimuksen viitekehystä. Luvussa 3 esittelen tutkimuksen aineiston ja menetelmät. Luvussa 4 esittelen analyysin ja tutkimuksen keskeiset tulokset. Luvussa 5 pohdin tutkimustuloksia ja niiden soveltamista vieraan kielen pedagogiikan kehittämiseen.

\section{EKOLOGINEN}

\section{LÄHESTYMISTAPA KIELENOPPIMISEEN}

'Perhaps, after all, we 'learn' language in the same way that an animal 'learns' the forest, or a plant 'learns' the soil."

(van Lier, 2000, s. 259)

Ekologisessa lähestymistavassa käytetään luontometaforaa sen kuvaamiseen, että ympäristön mahdollisuudet voivat avautua yksilölle tämän ollessa vuorovaikutuksessa sen kanssa. Yksilön kielenkäyttö on sidoksissa kontekstiin, ja sen avulla tämä voi mukautua kulloinkin käsillä olevaan tilanteeseen. (van Lier, 2000.) Vieraan kielen oppijoiden, kuten tutkimukseni amerikkalaisten suomenoppijoiden, onkin etsittävä kielenkäytön mahdollisuuksia ympäristöstään ja teknologian avulla aktiivisesti, koska he eivät asu kohdekielisessä ympäristössä. Opiskelijat joutuvat ikään kuin rakentamaan ympärilleen kohdekielisiä ympäristöjä. Esimerkiksi suomenoppija Owen päätyy tutkimuksessani esittelemään itsensä suomeksi sattumoisin kaupassa tapaamilleen suomalaisille (luku 4). Oppijan on hyödynnettävä tilaisuuksia kohdekielen käyttämiseen silloin kun niitä on tarjolla ja myös hakeuduttava näihin tilanteisiin aktiivisesti.

Ekologisessa lähestymistavassa kielen oppimista ei katsota prosessina, jossa kielellinen aines menee tai laitetaan "oppijan pään sisälle". Tutkimukseni avainosallistujat eivät omista tai hallitse kieltä, vaan elävät siinä. Oppimisessa oppija kehittää entistä tehokkaampia tapoja käsitellä maailmaa ja sen merkityksiä. (van Lier, 2000, 2004.) Tutkimuksessani tarkastelen kielenoppijoita erityisesti kielenkäyttäjinä: he osallistuvat vuorovaikutukseen sen hetkisillä resursseillaan ja kaikentasoisten suomenpuhujien kanssa. Kielitaito on tutkimukseni avainosallistujille vain yksi resurssi vuorovaikutuksen apuna: esimerkiksi keskustelu voidaan aloittaa suomeksi, jolloin funktiona on yhteyden luominen, ja sen jälkeen keskustelua jatketaan englanniksi. Kielitodellisuuteen myös mukaudutaan tarpeen mukaan: esimerkiksi suomenoppija Ivyn suomea osaamattomat Facebook-kaverit käyttävät Google-kääntäjää, jotta hekin voivat osallistua Ivyn suomeksi aloittamaan vuorovaikutukseen.

Tarkastelen yksittäisen oppijan kielellistä repertuaaria siis suhteessa tämän kohtaamiin kielenkäyttötilanteisiin. Analyysin kohteena on aktiivinen oppija ja tämän toiminta (van Lier, 2000). Van Lier (1996) kuvaa kielenoppimista seuraavien vaiheiden kautta: altistuminen (exposure), työstäminen (engagement), sisäistäminen (intake) ja taitaminen (proficiency) (suomennokset: Alanen, 2000). Vaiheet voivat limittyä toistensa kanssa. Koska tutkin oppijoiden toimijuutta ja sitä, miten he hakeutuvat itsenäisiin kielenkäyttötilanteisiin, olen kiinnostunut erityisesti altistumisen ja työstämisen prosesseista. 
Altistumisessa oppija kohtaa kohdekielistä ainesta, jonka hyödyntämisessä tarvitaan työstämistä. Oppijan työstäessä kieltä hänen sisäinen tietojärjestelmänsä on vuorovaikutuksessa ympäristön kanssa. (van Lier, 1996, s. 48-53.) Esimerkiksi tutkimuksessani Ivy altistuu suomen kielelle, kun hän vierailee uuden suomalaisen tuttavansa Mairen kotona ja keskustelee tämän kanssa suomeksi. Altistumisessa tärkeää on sen laatu ja määrä: altistuskielen pitää olla ymmärrettävää ja lisäksi oppija tarvitsee tukea, kuten kontekstuaalisia vihjeitä tai vuorovaikutuksessa saatua tukea (van Lier, 1996, s. 42-48).

Lisäksi tärkeitä ovat oppijan aiemmat kokemukset, kiinnostuksen kohteet ja asenteet. Oppijan tulee olla vastaanottavainen ja utelias altistuskieltä kohtaan. Kohdekielen käyttö vaatii panostusta. (van Lier, 1996, s. 46-53.) Ivy osoittaa kiinnostusta suomen kielen oppimiseen pyytämällä ystäväänsä kertomaan Suomen-matkastaan suomeksi, vaikka keskustelua voisi käydä englanniksikin. Altistuskielelle vastaanottavainen oppija kiinnittää siihen myös huomiota. Huomion kiinnittämisessä olennaista on kohdentaminen, jota ohjaa aineksen tuttuus tai tunnistettavuus. Oppija voi esimerkiksi poimia tuttuja teemoja käsittelevästä keskustelusta uusia sanastoaineksia. Tällaisissa olosuhteissa oppija voi hyödyntää altistuskielen tarjoumia oppimiseen. (van Lier, 1996, s. 49-7.)

\section{AINEISTO JA MENETELMÄT}

\subsection{Portfolioaineisto}

Artikkelin aineisto koostuu amerikkalaisen yliopiston neljän suomenoppijan, Owenin, Ivyn, Tinan ja Veran, portfoliomerkinnöistä, joita on yhteensä 36. Opiskelijoiden nimet on artikkelissa muutettu. Otanta on osa laajempaa tutkimusaineistoa, johon sisältyy artikkelin kirjoitushetkellä 99 portfoliomerkintää. Portfoliotehtävä, jonka suunnittelin yhdessä kollegani kanssa ${ }^{1}$, on ollut osa kurssiarviointia kolmella suomen kielen tasokurssilla. Tehtävässä opiskelijoiden täytyy kerätä kielenkäytöstään "todistusaineistoa", eli esimerkiksi nauhoituksia, kuvakaappauksia tai linkkejä, ja reflektoida oppimistaan kirjallisesti suomeksi tai englanniksi. Kuvaan eri vaiheet tiivistetysti kuviossa 1.

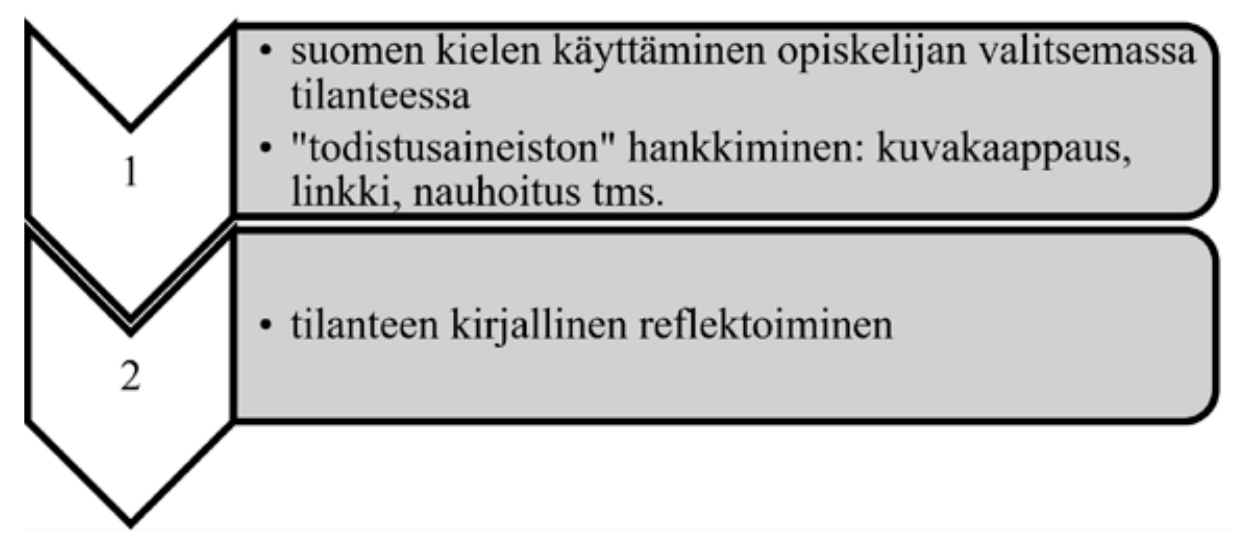

KUVIO 1: Portfoliotehtävän vaiheet

1 Kiitän Piibi-Kai Kivikiä, jonka kanssa suunnittelin portfoliotehtävän. 
Tarkoituksena on lisätä oppijoiden arkioppimista (incidental learning, ks. Kelly, 2012) ja itsenäistä kielen oppimista (autonomous language learning, ks. esim. Benson, 2001). Tavoite on 1) kannustaa ja "pakottaa” oppijoita luokkahuoneen ulkopuolella tapahtuvaan itsenäiseen kielenkäyttöön ja 2) tarjota opettaja-tutkijalle tietoa kielenkäytöstä (tutkiva opettaja, exploratory practice; ks. myös Hanks, 2017). Tavoitteena on, että oppijat aloittavat paitsi oppimisympäristönsä aktiivisen hyödyntämisen myös kielenkäyttönsä systemaattisen reflektoinnin. Reflektioissa oppija kohdistaa huomiotaan itseään kiinnostaviin aineksiin (ks. myös van Lier, 1996, s. 49).

Reflektioihin oppijat kirjoittivat havaintojaan ja analysoivat oppimistaan. Apukysymykset johdattelivat heitä pohtimaan muun muassa sitä, mistä asiasta he olivat pitäneet, minkä kokeneet haasteelliseksi ja mitä he olivat oppineet. Tässä artikkelissa analysoin oppijoiden kirjallisia reflektioita ja myös esimerkkejä alkuperäisistä kielenkäyttötilanteista.

Valitsemani avainosallistujat kirjoittivat portfolioissaan monipuolisista kielenkäyttötilanteista ja osoittivat erityisen aktiivista toimijuutta. Toisaalta myös muiden opiskelijoiden portfolioissa reflektoitiin samanlaisia teemoja, ja analyysini vahvistaa muistakin portfolioista tekemiäni havaintoja. Rajaus neljään avainosallistujaan mahdollistaa aineiston syvällisemmän tarkastelun.

Tutkimuksen osallistujat olivat yliopistotason opiskelijoita, jotka opiskelivat suomea kolmella eri vuosikurssilla. Suomen kurssit kokoontuivat 4-5 kertaa viikossa 50 minuutin ajan. Suurin osa osallistujista suoritti yliopistossa kandidaatin tutkintoa. Ivy ja Tina olivat keskenään samalla kurssilla, ja heiltä on portfolioita kolmen lukukauden ajalta. Owen oli vasta aloittanut suomen opintonsa, kun taas Vera oli jo pitkälle edennyt opiskelija, joka oli myös viettänyt aikaa Suomessa.

\subsection{Neksusanalyysi ja kielenoppijoiden tutkimus}

Käytän tutkimuksessa neksusanalyyttista lähestymistapaa, jossa yhdistetään diskurssintutkimuksen ja etnografian tutkimusperinnettä (ks. Pietikäinen, 2012, s. 419; Scollon \& Scollon, 2004). Scollon ja Scollon (2004) kehittivät neksusanalyysin tutkiessaan viestintäteknologioihin liittyviä sosiaalisia käytänteitä Alaskassa. Neksusanalyysia on hyödynnetty esimerkiksi tutkittaessa kielenoppimista verkostoituneena toimintana (ks. Kuure, Riekki \& Turmelius, 2018, s. 72, 74). Tutkimusprosessi tähtää kohteen muuttamiseen, ja sitä motivoi tutkijan itsensä havaitsema sosiaalinen ongelma (Scollon \& Scollon, 2004, s. 8-9), tässä tutkimuksessa ristiriita vieraan kielen opetusperinteen ja oppijoiden aktiivisen toimijuuden sekä muuttuneiden oppimisympäristöjen välillä. Lisäksi tutkimuksen tavoitteena on tarjota välineitä vieraan kielen pedagogiikan kehittämiseen.

Neksusanalyysia on hyödynnetty erilaisissa kielen oppimiseen ja kieli-ideologioihin liittyvissä tutkimuksissa. Amerikkalaisia suomen puhujia on aiemmin tarkastellut esimerkiksi Karjalainen (2012), joka sovelsi neksusanalyyttista lähestymistapaa amerikansuomalaisten kielielämäkertoihin ja tarkasteli kielen liikkuvuutta näiden siirtolaisten näkökulmasta. Kielen osittaiseenkin osaamiseen liittyy monia materialistisia ja ideologisia ulottuvuuksia. Ennen kaikkea osittainenkin kielitaito on kuitenkin resurssi, jonka hyödyntämismahdollisuudet vaihtelevat kontekstin mukaan. (Karjalainen, 2012.) Jatkan tässä artikkelissa samoja teemoja, mutta tarkastelen amerikkalaisia suomenoppijoita, jotka opiskelevat suomea vieraana kielenä ilman suomalaisia sukujuuria. Heillekin suomen kieli näyttäytyy juuri identiteetin rakentajana ja yhteyden luonnin välineenä enemmän kuin pelkkänä hyötyarvona (ks. Karjalainen, 2012, s. 230). 
Toisen kielen tutkimuksen kontekstissa on havaittu, että kielenkäyttö on tilanteista eli ajallisesti ja paikallisesti kerrostunutta. Kieliresurssien hyödyntämisessä keskeistä on oppijan oma toimijuus, ympäristön affordanssit ja sosiaalinen tuki. (Strömmer, 2017; Virtanen, 2017.) Kuure (2011) on tutkinut suomalaisten englanninoppijoiden verkkopeleissä tapahtuvaa kielenoppimista. Videopelit voivat tarjota kielen oppimisen affordansseja, jotka liittyvät sosiaalisten suhteiden ja vuorovaikutuksen rakentamiseen (Kuure, 2011). Myös omassa tutkimuksessani teknologialla on paljon vuorovaikutustarjoumia. Tässä artikkelissa keskityn erityisesti sosiaalisen median ja chatin tarjoumiin. Oman tutkimukseni osallistujat eivät opiskele globaalia valtakieltä, englantia. Internetissä he voivat kuitenkin samalla tavalla hakeutua kohdekielisiin tilanteisiin aktiivisen toimijuutensa ohjaamina.

Etenin tutkimuksessa Scollonin ja Scollonin (2004) menetelmäoppaan mukaan kolmivaiheisesti: 1) kartoittaminen, 2) navigointi ja 3) muokkaaminen (Pietikäisen, 2012, suomennokset). Kartoittamisvaiheessa tutustuin niihin sosiaalisiin toimintoihin ja toimijoihin, jotka ovat tärkeitä tutkimusongelman ratkaisemisessa, sekä keräsin aineiston. Navigoimisvaiheessa hain yhteyksiä ja merkityksiä havaitsemistani sosiaalisista toiminnoista eli analysoin tarkemmin opiskelijoiden portfolioissa dokumentoimaa vuorovaikutusta. Neksusanalyysiin kuuluu myös muokkaamisvaihe, jossa tutkija osallistuu uudelleen tutkimiinsa sosiaalisiin toimintoihin ja voi pyrkiä muokkaamaan niitä. (Scollon \& Scollon, 2004, s. 153-178.) Tämä tutkimus lähti liikkeelle tutkimuskentällä havaitsemastani muutostarpeesta, sillä olen pohtinut, vastaako opetukseni riittävästi oppijoiden todellisiin kielenkäyttötarpeisiin. Esitän toiminnan muuttamisen mahdollisuuksia luvussa 5.

Olen hahmottanut vuorovaikutuskumppaneiden ja kielenkäyttötilanteiden mo- ninaisuutta ja hierarkkisuutta piirtämällä portfolioissa dokumentoiduista sosiaalisista toiminnoista karttaa, jonka avulla pääsin kiinni tutkimuksen kannalta kiinnostaviin tilanteisiin. Tarkastelin useamman kerran kokonaisaineistoa suhteessa aiempaan tutkimukseen ja palasin aina takaisin valitsemieni avainosallistujien portfolioihin. (ks. myös Pietikäinen, 2012, s. 423.)

Kartoittamisvaiheessa työskentelyäni on helpottanut se, että asun ja työskentelen tutkimassani ympäristössä. Kielentutkimukselle on tyypillistä, että tutkija on itse mukana aineistossaan - olen tutkimuksen osallistujien suomen opettaja. Kartoittamisvaiheessa tieto kontekstista ja aineiston syvä tuntemus ovat auttaneet minua ymmärtämään tilannesidonnaisia viittauksia. Lisäksi minulla on syvällisempää ymmärrystä kielenoppimiskontekstista ja kohdeyliopiston suomen kielen opetusohjelman toimintaperiaatteista kuin täysin ulkopuolisella tutkijalla olisi. Oman organisaation tarkastelemiseen voi liittyvä kuitenkin monenlaisia haasteita, kuten luottamuksellisen suhteen säilyttäminen tutkimuksen kohteena oleviin (omat opiskelijani) (Alvesson, 2003). Tutkimuksen osallistujat tiesivät aineistonkeruun aikana tutkimuksestani vain, että sen tavoitteena on analysoida oppijoiden vuorovaikutusresursseja ja että tutkimusta on tarkoitus hyödyntää kielenopetuksen kehittämiseen. Portfoliotehtävä on osa opiskelijoiden kurssiarviointia, joten olen antanut siitä opiskelijoille palautetta. Olen kerännyt tutkimusluvat opiskelijoilta avustajan avulla ja vasta kurssiarvioinnin päätyttyä, jotta he voisivat varmistua siitä, että osallistuminen tai osallistumatta jättäminen ei vaikuttaisi heidän kurssisuoritukseensa.

Neksusanalyysiin liittyy kolme keskeistä käsitettä: toimijahistoria, paikan diskurssit ja vuorovaikutusjärjestys (Scollon \& Scollon, 2004, s. 19). Toimijahistoria (bistorical body) kuvaa aiempia kokemuksia ja olettamuksia, 
esimerkiksi tutkimuksessani avainosallistujien aiempia käsityksiä vuorovaikutustilanteista, tekstilajeista ja erilaisista kielenkäyttökonteksteista, esimerkiksi sähköpostista tai chatista genrenä. Toimijahistoria näkyy tutkimuksessani myös oppijoiden käsityksinä kielenoppimisesta. Myös van Lierin (1996) mukaan kielenoppijan aiemmat kokemukset ja esimerkiksi asenteet ovat tärkeitä kielellisen altistuksen työstämisessä. Paikan diskurssit (discourses in place) ovat esimerkiksi tilan materiaalisuuden, suunnittelun ja vuorovaikutustarjoumien mahdollistamia diskursseja (Scollon \& Scollon, 2004, s. 163). Tutkimuksessani nämä paikat ovat usein virtuaalisia tiloja, kuten sosiaalisen median ympäristöjä, mutta myös fyysisiä paikkoja: vuorovaikutusta tapahtuu pikaisesti kaupan lähettyvillä tai puoli-institutionaalisissa puitteissa suomen ohjelman järjestämällä keskustelutunnilla. Oppija käsittelee kielellistä altistusta suhteessa toimintaympäristöön ja sen tarjoamiin vuorovaikutustilanteisiin (van Lier, 1996).

Vuorovaikutusjärjestys (interaction order), johon keskityn tässä artikkelissa, käsittää erilaiset sosiaaliset järjestelyt ja hierarkiat (Scollon \& Scollon, 2004, s. 19), tutkimuksessani esimerkiksi sen, miten asiantuntevien kielenkäyttäjien ja kielenoppijoiden vuorovaikutus rakentuu hierarkkisesti. Vuorovaikutuksen osapuolet määrittävät toisiaan yksilöinä ja sosiaalisten valtarakenteiden kautta (Goffman, 1983 , s. 3). Tutkimuksessani vuorovaikutusjärjestys rakentuu sen mukaan, miten osapuolet mär̈rittävät omaa ja vuorovaikutuskumppaninsa kielitaitoa (kieltä osaamaton, alkeisoppija, edistyneempi kielenoppija, asiantunteva kielenkäyttäjä, kielenopettaja). Käytän Ramptonin (1995) asiantuntijan käsitettä kuvaamaan niitä avainosallistujieni vuorovaikutuskumppaneita, joiden kielitaito on niin vakiintunut, että he eivät ole artikkelissa kuvatuissa tilanteissa kielenoppijan roolissa. Tutkimukseni monikielisessä todellisuudes- sa asiantuntijuus kuvaa näitä osallistujia paremmin verrattuna esimerkiksi äidinkieliseen puhujaan, johon liittyisi erilaisia ideologisia ulottuvuuksia: Asiantuntija tai asiantunteva kielenkäyttäjä määrittyy osaamisensa, ei syntyperänsä kautta. Asiantuntijuus määräytyy myös suhteessa vuorovaikutuskumppaniin. (Rampton, 1995, s. 340-341.) Luvussa 4.3 avainosallistujani esiintyvät itse asiantuntijan roolissa, koska he ovat kielellisiltä resursseiltaan kieliasiantuntijoita suhteessa suomen kieltä osaamattomiin ystäviinsä ja perheenjäseniinsä. Asiantuntijuus siis riippuu siitä, miten vuorovaikutuksen osapuolet asemoivat itseän suhteessa toisiinsa. Tässä artikkelissa perehdyn erityisesti siihen, miten oppijanrooli ja toisaalta oppijan panostus ja aktiivinen toimijuus vaikuttavat vuorovaikutusjärjestyksen rakentumiseen.

\subsection{Diskurssianalyysi}

Analyysimenetelmäni on diskurssianalyysi, joka Scollonin ja Scollonin (2004) kenttäoppaan mukaan sopii navigointivaiheen välineeksi, kun tarkastellaan hierarkioita ja vuorovaikutusta. Diskurssianalyysin avulla tarkastelen, miten avainosallistujat reflektoivat omaa toimijuttaan ja vuorovaikutustaan asiantuntevien kielenkäyttäjien kanssa (Scollon \& Scollon, 2004, s. 173-174). Diskurssianalyysissa kieltä tarkastellaan sosiaalisena toimintana käyttökontekstissaan suhteessa "kielenkäyttäjien sosiaalisiin käytänteisiin ja rakenteisiin" (Pietikäinen \& Mäntynen, 2019).

Neksusanalyysin mukaisesti analyysin kohteina ovat sekä toiminnan makro- että mikrotaso. (Pietikäinen, 2012, s. 417.) Makrotasolla olen esimerkiksi kiinnostunut siitä, millaiseen kielenkäyttötilanteeseen oppija osallistuu ja mitä tilanne paljastaa oppijanroolista. Mikrotasolla olen kiinnostunut vuorovaikutuksen rakentumisesta ja siitä, miten oppija sanallistaa oppimaansa - tässä olen käyttänyt diskurssianalyysia. Keskityn analyysissa oppijoiden 
dokumentoimiin vuorovaikutustilanteisiin sekä niissä esiin nouseviin oppijan havaintoihin, joihin oppija kiinnittää huomiota kirjallisissa reflektioissa tilanteen päätyttyä. Reflektointikin on sosiaalista toimintaa: Reflektioissa oppijat jäsentävät ja merkityksellistävät kielenkäyttötilanteita jälkikäteen opettajalle. Lisäksi he kielentävät näille kokemuksille antamiaan merkityksiä.

Artikkelissa en ota varsinaisesti kantaa siihen, millaista oppimista portfoliotyöskentelyn aikana tapahtuu, vaan kuvaan ja analysoin, miten oppijat näitä kokemuksia merkityksellistävät. Analysoin siis, mitä oppija on oman kuvauksensa mukaan kielellä tehnyt ja mitä hän tilanteesta kirjoittaa. Oppija esimerkiksi kertoo harjoitelleensa imperfektin käyttöä suomalaisen kaverin kanssa pyytämällä tätä kertomaan menneestä lomamatkastaan. En kuitenkaan analysoi, onko opiskelija oppinut imperfektin käyttöä tämän harjoittelutilanteen myötä.

\section{TOIMIJUUS JA}

VUOROVAIKUTUSJÄRJESTYKSEN RAKENTUMINEN ITSENÄISISSÄ KIELENKÄYTTÖTILANTEISSA

Portfolioissa osallistujat kuvaavat osallistumistaan erilaisiin suullisiin ja kirjallisiin suomenkielisiin vuorovaikutustilanteisiin asiantuntevien suomenpuhujien, muiden suomenoppijoiden sekä jopa suomea osaamattomien henkilöiden kanssa. Vuorovaikutus voi olla kasvokkaista tai teknologiavälitteistä. Vuorovaikutustilanteet näyttäytyvät aineistossa opiskelijoille keskeisimpänä suomenkielisen toiminnan ja kieliharjoittelun tarjoumina (ks. myös Suni, 2008). Ne rakentuvat tilanteissa usein hierarkkisesti: oppija ohjaa toimintaa omalla aloitteellisuudellaan ja vuorovaikutuskumppanit toimivat tilanteissa usein asiantuntijan roolissa. Kartoittamisvaiheessa hahmotin portfolioissa esiin nousevia suhteita ja sosiaalista verkottunei- suutta. Vuorovaikutustilanteiden osapuolet rakentavat identiteettiään sosiaalisessa vuorovaikutuksessa ja ottavat tilanteen mukaan itselleen erilaisia väliaikaisia rooleja (Bucholtz \& Hall, 2010, s. 18-20). Itsensä asemoiminen oppijaksi tai asiantuntevaksi kielenkäyttäjäksi vaikuttaa merkittävästi vuorovaikutusjärjestyksen rakentumiseen. Keskeiseksi nousee oppijan aktiivinen toimijuus.

\subsection{Oppija aloitteentekijänä ja vuorovaikutustilanteen ohjaajana}

Alkeisoppijoiden portfolioissa vuorovaikutuksen hierarkiat näyttävät rakentuvan osallistujien kielitaidon tason mukaan: oppijalla ja asiantuntevalla suomen puhujalla on vuorovaikutustilanteessa omat roolinsa. Vuorovaikutuksen alulle panijana on portfolioissa oppija, jonka ehdoilla keskustelu etenee. Asiantunteva kielenkäyttäjä osallistuu vuorovaikutukseen oppijan säätelemien raamien puitteissa.

Alkeisopiskelijat kuvaavat portfolioissa tilanteita, joissa he ovat osallistuneet viestintään monikielisesti osittaisella kielitaidolla. Kukaan ei hallitse mitään kieltä "kokonaan" eli ole sen "täydellinen” puhuja. Kukaan ei myöskään tarvitse kaikkia kielen resursseja arkielämässään. Globaalissa ajassa juuri kielenkäytön osittaisuus ja monilähtöisyys on tärkeä analyysin kohde. (Blommaert, 2010, s. 103, 106.) Reflektioissa oppijat kiinnittävät huomiota mahdollisuuksiinsa osallistua vuorovaikutukseen suomen kielen resursseillaan.

Esimerkiksi suomen kielen opintonsa vasta aloittanut Owen kirjoittaa kohtaamisestaan kaupassa. Hän on huomannut, että kassalla asioivat ihmiset vaikuttavat puhuvan suomea. Kassahenkilö on kysynyt heiltä heidän kotimaastaan ja Owenille on varmistunut, että he ovat suomalaisia. Tämän jälkeen Owen on mennyt juttelemaan heille. Olen lihavoinut Owenin reflektioon kohdat, joihin kiinnitän analyysissa erityistä huomiota. 


\section{Esimerkki 1}

When we had both walked out I said, "Moi!" and they were happy to hear that I knew a little Finnish. I attempted to introduce myself in Finnish, and we had a very brief conversation about my studying Finnish. It was exciting to be able to use Finnish to be able to relate to other people I come across in my everyday life.

Esimerkissä Owen korostaa suomen kielen käytön vähyyttä kohtaamisessa sananvalinnoillaan a little ja I attempted to. Owenin sananvalinnat korostavat hänen osallistumisensa yksilöllistä puolta: kuvauksesta syntyy vaikutelma Owenin performanssista, jonka yleisönä suomalaiset kuulijat ovat olleet. Tämän jälkeen on vaihdettu englannin kieleen. Englanninkielistä vuorovaikutusta Owen kuvaa keskusteluksi. Tervehdykset ja itsensä esitteleminen opitaan suomen kurssilla ensimmäisenä ja niillä on luontevaa aloittaa keskustelu. Abstraktimman tason keskusteluun siirryttäessä kielenvaihto on luontevaa, koska osallistujat ovat kaikki englanninkielentaitoisia.

Oppijan kiinnostus ja vastaanottavaisuus ohjaavat häntä altistumaan kielelle (van Lier, 1996, s. 46). Owenin reflektiosta näkyy vastaanottavaisuus altistuskielelle: hän suhtautuu kohtaamiinsa suomalaisiin eräänlaisena kielenkäytön tarjoumana. Kun hänelle tarjoutuu pienikin mahdollisuus käyttää suomen kieltä, hän hyödyntää sen. Kielenoppijat, nekin, jotka näennäisesti elävät samanlaisessa ympäristössä, havaitsevat asioita eri tavoilla (Menezes, 2011, s. 61). Paikan diskurssien syvempi analyysi on muun kuin reflektioaineiston puuttumisen vuoksi haastavaa, mutta Owenin kuvauksen perusteella kaupan ulkopuolella on yllättäen tarjoutunut tilaisuus lyhyeen keskusteluun: tilanteen hetkittäisyys on ehkä juuri ollut kannusteena siihen tarttumisessa. Kuvauksen perusteella molemmat keskustelun osapuolet ovat yllättyneet tilanteesta positiivisesti, sillä kyseisessä amerikkalaisessa yliopistokaupungissa ei ole tyypillistä törmätä suomenkielisiin. Tarjoamat ovat tärkeitä toimijuuden muodostumisessa ja niitä ei voi irrottaa kontekstistaan (Mercer, 2012, s. 46-48).

Seuraavassa esimerkissä Ivy, joka on tässä vaiheessa opiskellut suomea puolisen vuotta, reflektoi vierailuaan suomalaisen Mairen luona. Maire on Ivyn asuinkaupungissa asuva suomalainen, johon tämä on tutustunut sattumalta kaupassa. Näitä sattumuksia esiintyy portfolioaineistossa paljonkin, mikä kertoo siitä, että opiskelijat ovat olleet erityisen vastaanottavaisia altistamaan itseään mahdollisille kielenkäytön tarjoumille. Ivy menee Mairen luo kylään tavoitteenaan tutustua tähän paremmin ja harjoitella suomen kielen käyttöä:

\section{Esimerkki 2}

- - Me enimmäkseen puhuemme englantia ja vähän suomea. - - I was surprised at how easy it was to say simple greetings with her! Getting to know each other, we mainly spoke in English. - - She agreed to meet with me regularly to speak Finnish - I told her how I had just learned "past tense" earlier that day, and she spoke of what we had done during our visit in Finnish.

Ivyn sananvalinnoissa korostuu yhteisen tekemisen merkitys. Suurin osa kuvauksesta on me-muodossa. Kuvauksen loppuosa rakentuu Ivyn pyyntöjen ja sitä seuranneen toiminnan kaavalla. Ivyn pyyntö on kummassakin tapauksessa synnyttänyt vuorovaikutuskumppanissa myönteisen vastauksen. Esille nousee siis toiminnan vastavuoroisuus eli se, että toimintaan vastataan toiminnalla.

Van Lierin (1996, s. 53-54) mukaan oppijan panostus on olennaista kielen prosessoinnissa. Ivyn reflektio kertoo siitä, miten hän pyrkii aktiivisesti hyödyntämään vuorovaikutusti- 
lanteen kieliharjoitteluun. Hän menee vierailulle Mairen luokse tavoitteenaan harjoitella tämän kanssa suomea sekä pyytää Mairea harjoittelemaan kanssaan myös jatkossa. Norton ja Toohey (2001) ovat tarkastelleet kahden tapaustutkimuksen kautta "hyvän kielenoppijan” ominaisuuksia. Tutkimuksen mukaan hyvä kielenoppija hyödyntää yhteisöjä vuorovaikutukseen (Norton \& Toohey, 2001). Ivy kertoo Mairelle, mitä hän on oppinut kurssilla, tavoitteenaan kohdistaa harjoittelua juuri opittuun imperfekti-rakenteeseen. Hän hyödyntää uutta tuttavaansa tarjoumana rakenteen oppimiseen. Oppijan ja asiantuntevan suomenpuhujan vuorovaikutus rakentuu siis aineistossa usein hierarkkisesti. Portfoliotehtävässä aloitteentekijä on oppija, joka hyödyntää vuorovaikutuskumppaniaan eli asiantuntevaa suomenpuhujaa altistuakseen kohdekielelle.

Alkeisoppijan ja edistyneen suomenpuhujan keskustelut ovat aineistossa usein haastattelumaisia tai ne jäsentyvät kuten opetustilanne. Vuorovaikutustilanteen haastattelumaisuus näkyy oppijoiden toimittamissa video- tai äänitiedostoissa, mutta oppijat myös itse nimeävät tilanteita haastatteluiksi. Esimerkiksi Ivy on opettajan kehotuksesta nauhoittanut erään Mairen kanssa käymänsä suomenkielisen keskustelun, joka rakentuu Ivyn kysymysten ja Mairen vastausten varaan.

Ivy reflektoi keskustelua esimerkissä 3:

\section{Esimerkki 3}

Se oli hidas keskustelu ja enemmän kuten haastattelu kuin mä haluaisin, mutta se oli okei!

Raportissaan Ivy nimeää oman toimintansa haastatteluksi. Diskurssin nimeäminen synnyttää vastuuvelvollisuuden (Enfield \& Sidnell, 2017, s. 517) eli Ivy ikään kuin osoittaa tyytymättömyytensä keskustelun haastattelumaisuudesta. Hän kuitenkin "puolustautuu" toteamalla mutta se oli okei. Haastattelumaisuus on tässä tilanteessa ollut hyväksyttävää ehkä juuri Ivyn oppijaroolin vuoksi. Haastattelutilanteessa kysyjällä ja vastaajalla on selkeät roolit, ja asiantuntevan kielenkäyttäjän eli vastaajan tehtäväksi jää ymmärtää oppija-haastattelijaa ja reagoida esitettyihin kysymyksiin vastauksillaan.

Haastattelu vaikuttaa portfolioissa olevan oppijoille luonnollinen tapa osallistua suulliseen vuorovaikutukseen kielellä, jota he hallitsevat vasta vähän: kysymyksien esittäminenhän opitaan usein kieliopintojen alkuvaiheessa, ja kysymykset ovat muodoltaan vakiintuneita. Vastaaminen puolestaan vaatii pidempää reflektoimista ja monipuolista kielitaitoa. Haastattelumaisuus johtunee lisäksi tyypillisestä oppijan roolista. Taustalla näkyy ehkä osapuolten toimijahistoria eli käsityksiä edistyneen kielenkäyttäjän ja oppijan välisestä rakenteellisesta hierarkiasta. Edistyneellä kielenkäyttäjällä on käytössään enemmän kohdekielisiä resursseja.

Useassa portfoliomerkinnässä oppijat kirjoittavat, kuinka asiantunteva kielenkäyttäjä on alkanut keskustelun aikana opettaa kieltä kielenoppijalle tai kuinka kielenoppija on itse alkanut hyödyntää tätä opettajanaan. Tina on osallistunut suomen kielen kahvitunnille ja pyytänyt kahvitunnin vastuuhenkilönä toimivaa opetusassistenttia opettamaan hänelle kaunokirjallisuuteen liittyvää sanastoa ja fraaseja:

\section{Esimerkki 4}

- - mä leun paljon ja mä tarvitsen sanat puhua kirja. - - opin paljon uusia sanat. Esimerkiksi kuningas ja salamurhaaja, koska mä puhuin kirja mä luin. - - it was super cool to incorporate Finnish into - - my hobbies - -. Next time I would definitely take better notes, because I don't remember all the words that (opetusassistentti) taught us that day. 
Tinan $m \ddot{a}$-pronominit korostavat tapahtuman yksilöllistä merkitystä Tinan oppimiselle. Kuvauksesta ei käy ilmi, onko paikalla ollut muita kuin hän ja assistentti. Keskustelukumppaniin viitataan ainoastaan Tinan toiminnan apuvälineenä. Tina kuvaa opetusassistentin toimintaa opettamiseksi. Omaa toimintaansa Tina kuvaa puhumiseksi ja oppimiseksi. Tina käsittelee informaalia kahvituntia ikään kuin oppituntina, jossa oppija saa valita opetuksen sisällön ja kulun.

Aktiivinen toimijuus rakentuu suhteessa toimintaympäristöön ja siihen, miten oppija ympäristön tarjoumia hyödyntää (van Lier, 2004). Kahvitunti tarjoaa kielenkäytön harjoittelulle puitteet eli fyysiset ja sosiaaliset raamit. Oppija voi hyödyntää tilannetta monella tavalla. Jo kahvitunnille saapuminen on ensiaskel tarjouman hyödyntämiseen. Oppija voi aktiivisella osallistumisellaan kuitenkin pyrkiä saamaan tilanteesta itselleen maksimaalisen hyödyn. Hiljaa olemalla tai esimerkiksi englantia puhumalla oppija saisi kahvitunnista vähemmän mahdollisuuksia suomen kielen käytön harjoitteluun.

Nykyaikana vieraan kielen oppijan ei tarvitse kuitenkaan aina hakeutua tai "törmätä" kielenkäyttötilanteisiin altistuakseen niihin fyysisessä lähiympäristössään. Teknologia tuo vuorovaikutuskumppanit metaforisesti mutta kirjaimellisestikin käden ulottuville eli tarvitaan vain toimiva laite ja sovellus sekä verkostoja, joihin olla yhteydessä. Verkostot voivat olla missä vain. Seuraavaksi esittelen tilanteita, joissa oppijat hyödyntävät sosiaalista mediaa vuorovaikutuksen apuna.

Ivy hyödyntää suomenpuhujien verkostojaan sosiaalisessa mediassa. Ivy on laittanut portfolioonsa kuvakaappauksia Facebookpäivityksistään sekä oman alkuperäisen postauksensa ja siihen saadut kommentit ${ }^{2}$. Hän reflektoi kielenkäyttötilannetta esimerkissä 5:

\footnotetext{
2 En sisällytä Ivyn alkuperäisiä kuvakaappauksia tähän suojellakseni hänen sekä hänen Facebook-kavereidensa anonymiteettiä.
}

\section{Esimerkki 5}

Mun Englatia kieli puhuminen kavereja Facebook:ssa nauttavat mun posteja suomea kielissa. He voisivat käänökset mun kirjoitan koska Facebook antaa käänökset montille kielille. - - Mun käverit ovat kerrottu minä etta he pidävät lue mun Suomen kirjoittaminen Facebook:ssa. Mulla on muutama Suomalainen käverit Facebook:ssa, mutta he vastavat harvoin mun postejä. - - Mä toivon he voisivät vastaa minun postejä Suomea kielissa! Ehkä yksi päivä. Mä usein postin mun kissojästä, mun koirasta - - Se on hauska kun mä muistan Suomea kieli ja mä en tarvitsee katsoo sitä sanoja!

Reflektion alussa Ivy kirjoittaa Facebookkavereistaan ja heidän toiminnoistaan ja ajatuksistaan kontrastina omalle toiminnalleen. Tämän jälkeen hän kirjoittaa omasta toiminnastaan mä-pronominiviittauksilla asettaen ystävien toiminnan vastakkain oman toimintansa kanssa. Vastakkainasettelua lisää mutta, joka "aiheuttaa adversatiivisen suhteen lauseiden välille" (VISK § 1102) sekä adverbiaalit usein ja harvoin / yksi päivä. Ivy siis asemoi itsensä aktiiviseksi sisällön jakajaksi ja suomalaisen yleisönsä passiivisiksi vastaanottajiksi, jotka eivät osallistu vuorovaikutukseen.

Yhteisöt ovat tärkeitä kielenoppimiselle (Norton \& Toohey, 2001, s.314-316). Teknologia voi tarjota kielenoppijalle runsaasti vuorovaikutusmahdollisuuksia, ja oppijat voivat sen avulla rakentaa yhteisöllisyyttä sekä päästä osaksi kansainvälisiin yhteisöihin. Facebook mahdollistaa kertomisen henkilökohtaisista arkisista asioista, kuten lemmikeistä. Tilapäivitysten postaaminen voi olla yksipuolista jakamista, mutta siinä on myös mahdollisuus vastavuoroisuuteen. Ivy kiinnittääkin huomionsa viestien vastaanottajiin. Reflektiossa on paljon positiivisia adjektiiveja. Amerikkalaiset ystävät ilahtuvat päivityksistä ja osallis- 
tuvat vuorovaikutukseen käännöstyökalun avulla. Ivy tuo esille myös suomea puhuvan verkostonsa potentiaaliset tarjoumat, jotka jäävät osittain toteutumatta, koska suomalaiset kaverit eivät vastaa hänen viesteihinsä.

Ivy reflektoi portfoliossaan Facebookin tarjoumia suomenkieliselle vuorovaikutukselle. Sosiaalisessa mediassa on monia tarjoumia autenttiseen kielenkäyttöön (Leppänen, Vaarala \& Taalas, 2019, s. 103). Ivy kirjoittaa Facebookin käännösominaisuudesta (ks. myös Alm, 2016, s. 9-10) ja siitä, miten se hyödyttää vuorovaikutuksessa: suomea osaamattomat ystävät voivat kääntää päivitykset omalle kielelleen. Ivyn ja hänen kontaktiensa Facebookvuorovaikutuksessa näkyy myös huumorin merkitys. Amerikkalaiset Facebook-kaverit käyttävät käännöstoimintoa suomenkielisen päivityksen ymmärtämiseen ja luovat huumoria käännöksen perusteella.

Teknologia ja digitaaliset viestintävälineet mahdollistavat sen, että amerikkalaiset opiskelijat voivat olla yhteydessä myös kaukana asuviin suomalaisiin tuttaviinsa, mikä kuitenkin usein vaatii oppijoilta erityistä aloitteellisuutta. Tutkimuksessa oppijat ottavat yhteyttä tuttuihinsa, joiden kanssa he eivät ehkä ole puhuneet toviin tai joiden kanssa he tavallisesti keskustelevat englanniksi. Vera on opiskellut suomea hetken aikaa Suomessa ja aloittanut sitten opinnot amerikkalaisessa yliopistossa. Suomessa olosta on jo hiukan aikaa, ja Vera kirjoittaa sähköpostiviestin entiselle suomen kielen opettajalleen:

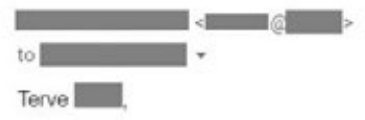

Fri, Feb 1, 3.37 PM (7 days ago)

Terve

\begin{abstract}
Se on Minulla oli sinun johdantokurssi vuonna — ja En tiedă jos sină muistat minua, mutta mină halusin sanoa mină löysin suomen kieli kurssi kun mina menin kotiin. Minun yliopistolla (_ on suomen kieli kurssi ja mina jatkoin toisella tasolla. Myös mina muutuin minun opinnot yliopistossa. Opiskelen__ opinnot (keskus suomessa) ja minun sivuaine on opettaa englantia samalla tavalla sina opetat suomea. Toivottavasti sina olet terveellinen ja onnellinen. Kiitos sinun opetuksesta, silla oli suuri vaikutus
\end{abstract} minun elamassa.

Kiitos paljon,

KUVA 1. Veran sähköposti

Viestissä Vera esittelee itsensä tavalla, joka viittaa siihen, että kohtaamisesta on ollut aikaa. Viesti on kuin kiitospuhe, jossa vastakkain ovat Veran oma mahdollisesti vähäinen merkitys opettajan elämälle (esittely ja en tiedä jos sinä muistat minua) ja toisaalta opettajan suuri merkitys Veran elämäntarinassa. Tässä näkyy jälleen oppijan aloitteellisuuden rooli. Vieraan kielen oppijan on oltava aloitteellinen altistaakseen itsensä kohdekielelle. Vera analysoi opettajan vastausviestiä esimerkissä 6:

\section{Esimerkki 6}

Hän (opettaja) vastasi mulle ja sanoi oli kiva kuulla minusta. Myös mä opin uusia fraasia, "lämmittää sydäntä" ja "sydämessäni paistaa aurinko. - - Varmasti koska hän on kielen opettaja, ei ole mitään vaikea ymmärtää sähköpostissa. - - Jos mun täytyy kirjoittaa toinen sähköposti se olisi tosi samanlainen koska mä ajatellen ei ollut ongelma ymmärtämisessä. Mä käytin kirjakieli koska on sähköposti, ehkä mä voisin käyttää puhekieli mutta kirja kieli oli sopiva. 
Vera referoi sähköpostin sisältöä tyypillisin raportointiverbein. Opettajan vastaus on reflektion perusteella lämminsävyinen, mikä näkyy myös opettajan käyttämistä kielikuvista. van Lierin (1996) mukaan on tärkeää, että oppija kiinnittää huomiota kohdekieleen. Jo huomion kiinnittäminen on aktiivista työstämistä. Kielikuvat ovat kiinnittäneet Verankin huomion. Vera hyödyntää opettajan vastausviestin ikään kuin oppimateriaalina. Hän analysoi reflektiossaan opettajan käyttämiä idiomeja ja niiden merkitystä. Asiantunteva kielenkäyttäjä tarjoaa oppijalle altistuskieltä, jota hän voi työstää.

Vuorovaikutusaloite on tullut Veralta itseltään ja Veran reflektiosta näkyy tyytyväisyys viestinnän onnistumiseen. Vera analysoi omaa ja opettajan kielellistä toimintaa varmoin sanankääntein: varmasti, ei ole mitä̈n vaikea, olisi tosi samanlainen, oli sopiva. Hän esittää mahdollisuuksia vaihtoehtoiselle toiminnalle mutta kumoaa ne saman tien, ikään kuin perusteluna oman toimintansa onnistuneisuudelle. Viestintätavoite on täyttynyt, koska molemminpuolisessa ymmärryksessä ei ole ollut ongelmaa. Lisäksi Vera pohtii rekisterin valintaa. Hän kirjoittaa käyttäneensä sähköpostissa kirjakieltä tekstilajin vuoksi, mutta pohtii myös, olisiko puhekielikin ollut sopiva valinta. Portfoliotehtävä on ollut Veralle kimmoke olla yhteydessä entiseen opettajaansa ja kertoa tälle kuulumisistaan. Samalla hän on saanut mahdollisuuden ehkä myös esitellä lähtönsä jälkeen kehittynyttä kielitaitoaan.

\subsection{Oppijan pyrkimys vastavuoroisuuteen}

Alaluvun 4.1 esimerkeissä oppijan ja keskustelukumppanien vuorovaikutusjärjestys on hierarkkisesti rakentunutta. Oppija ohjaa toimintaa omalla aloitteellisuudellaan ja todelliset sekä potentiaaliset vuorovaikutuskumppanit vastaavat aloitteellisuuteen omalla toiminnallaan niin, että oppija saa tilanteesta hyödyn ja asiantunteva kielenkäyttäjä tarjo- aa tälle kielellistä altistusta. Toisaalta useissa portfolioissa näkyy myös oppijan pyrkimys osallistua vuorovaikutukseen tasavertaisena keskustelukumppanina, jota ei määrittäisi oppijan ja asiantuntevan kielenkäyttäjän roolit. Tämä näkyy erityisesti pidemmällä suomen opinnoissaan olevien opiskelijoiden reflektioista tai silloin, kun oppija on käyttänyt kieltä samantasoisen oppijan kanssa.

Vera on asunut aiemmin Suomessa ja nyt hän on pitänyt yhteyttä suomalaiseen ystäväänsä Maijaan chattailemalla. Oheinen esimerkki on ote pitkästä keskustelusta.

näytinkö jo kuvia sinlle penkkareista 2:39 PM

sinulle $e^{\star}$

Ehkä ei, mutta unohdin mikä penkkari on

2:40 PM $\checkmark$

Nyt mä muistan

Mä googlasin sen

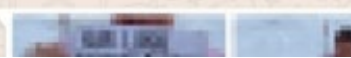

KUVA 2. Veran (oikealla puolella) sekä Maijan (vasemmalla puolella) välinen WhatsApp-keskustelu

Esimerkissä 2 kuvattu katkelma on osa pidempää keskustelua. Tässä chat-keskustelussa vuorojen otot jakautuvat tasaisemmin kuin luvun 4.1 esimerkeissä. Valitsemassani esimerkissä Veran keskustelukumppani vaihtaa aiheen penkkariteemaan. Maijan kysymysmuotoinen viesti on avauksena penkkarikuvien jakamiselle ja niistä keskustelulle. Vera vastaa kysymykseen kohdentaen huomionsa penkkari-sanaan. van Lierin (1996, s. 49-51) mukaan onkin tyypillistä, että oppija kohdentaa huomionsa hämmennystä aiheuttavaan ainekseen kohdekielelle altistuessaan. Keskustelukumppani kuitenkin ohittaa Veran sanastopohdinnat ja jatkaa keskustelua jakamalla penkkarikuvansa. Vera kertoo chatissa katsoneensa sanan Googlesta. Sanan etsimi- 
nen ei kuitenkaan juuri hidasta vuorovaikutusta, sillä Vera vastaa kuvaviestiin minuutin kuluttua ensimmäisestä viestistä.

Teknologian käyttö voi murtaa hierarkioita oppijan ja asiantuntevan kielenkäyttäjän välillä. Sosiaalisen median avulla oppijat voivat harjoitella kielenkäyttöä vapaa-ajallaan ajasta ja paikasta riippumatta (ks. myös Leppänen ym., 2019, s. 110). Esimerkiksi chat-viesteissä vuorovaikutus on usein tasavertaista kahden samanikäisen opiskelijan välistä keskustelua. Kommunikaatiokatkos, kuten Veran tapauksessa sanan unohtaminen, ei vaikeuta vuorovaikutusta, koska sanan tarkistaminen onnistuu nopeasti ja katkos jää lyhyeksi. Vuorovaikutus siis rakentuu luontevasti kahden ystävän vuoropuheluna, eivätkä Veran ja Maijan roolit suomenoppijana ja asiantuntevana puhujana juuri korostu keskustelussa.

Vera kuitenkin kommentoi reflektiossaan Maijan viestejä:

\section{Esimerkki 7}

Maija lähetti viestejä kirjakielessä usein. Ehkä on koska hän tietää mä olen suomen opiskelija ja kirjakieli olisi helpompi mulle, mutta mun mielestä olisi hyvä idea oppia puhekieli vai slangi tekstissä.

Reflektiossa vastakkain asettuvat Veran toiveet ja Maijan toiminta. Konjunktio mutta korostaa kontrastia ystävän toiminnan ja Veran toiveen välillä. Myös muissa portfolioissa pohdittiin valintaa kirjakielen ja puhekielen välillä sekä tarvetta oppia autenttista kirjallista vuorovaikutusta. Näissä tapauksissa yleiskielisen rekisterin valinta, ainakin oppijan itsensä mukaan, asemoi tämän oppijaksi (kielenoppimis- ja kielenopetusrekisteri; Lehtonen, 2015, s. 213). Esimerkiksi Maija käyttää kuvan 2 esimerkissä toisen persoonan pidempää allatiivimuotoa sinulle, joka voidaan kokea ideologisesti yleiskieliseksi: Persoonapronominien pidemmät taivutus- muodot mielletään usein osaksi opetusrekisteriä tai ulkomaalaispuhetta (Lehtonen, 2015, s. 215). Sosiaalisen median teksteissä taivutusmuotojen käytössä on on usein paljon enemmän variaatiota kuin painetuissa teksteissä, ja sosiaalisen median käyttäjät joutuvat kiinnittämään rekisteriin eri tavalla huomiota (ks. esim. Leppänen ym., 2019, s. 97). Chatissa kirjoittaminen on usein reaaliaikaista, mikä näkyy rekisterin valinnassa. Viestittely ei ole huoliteltua yleiskielistä tekstiä, vaan keskustelunomaista vuorovaikutusta, puhekieltä. Toisaalta maallikko saattaa käsittää juuri kirjoitetun yleiskielen kielenoppijalle helpoimmaksi variantiksi. Kielten alkeisopetuksessa on vaihtelevia käytänteitä siitä, missä määrin puhe- ja kirjakieltä opiskellaan. Tutkimuksen kohteena olevassa suomen ohjelmassa pääpaino on ollut puhekielessä, mikä on kaiken kaikkiaan käsittääkseni harvinaisempaa. Oppijan toive puhekielisemmästä keskustelusta vaikuttaa samalla toiveelta tulla kohdelluksi vertaisena keskustelukumppanina.

\subsection{Oppija kieliasiantuntijana}

Koska tutkimukseni vieraan kielen oppimisen kontekstissa oppijoiden altistus kohdekielelle omassa elinympäristössään on usein vähäistä, oppijat lisäävät mahdollisuuksia suomen kielen käyttöön omalla aktiivisella toiminnallaan. He jopa tuovat suomen kieltä aktiivisesti osaksi lähipiirinsä arkea. Portfolioissa onkin paljon kuvauksia tilanteista, joissa oppijat ovat opettaneet suomea amerikkalaisille perheenjäsenille ja ystävilleen.

Tina kirjoittaa viikonlopustaan esimerkissä 8: 


\section{Esimerkki 8}

- - tämä vikkonloppuna mä tapasin paljon ihmisiä. Kun mä puhuin ihmista kanssa ja sanoin että mä opiskelen suomen kieltä, he he ajattelivat, että se oli siistiä. Jotkut heistä kysyivät "mitä kuulostaa kuin?”. Niin mä puhuin vähän suomea heille ja mä opetin heille joitain sanoja. - - Se oli tosi hauska jakaa suomen kieli ihmiset kanssa. Mä mielesta se on hyvä ja helppo tapa esitellä ihmisiä Suomeen ja suomen kieli ja ehkä kielten oppiminen. Mun perhe ja mun serkku tietävät sana "joo" koska mä käytän sitä paljon joskus sijaan "yes". - - se saa perheeni ja kaveri nauramaan joten se on hauska.

Kuten esimerkki 2, tämäkin kertomus etenee hierarkkisesti toiminta-seuraamus-periaatteella: kun mä tein näin - he tekivät näin ja kun he kysyivät - niin mä pubuin ja opetin. Tällä kertaa roolit ovat kuitenkin vaihtuneet eli oppija on toiminut tilanteessa asiantuntijana, joka on tuonut altistuskieltä tilanteeseen. Vuorovaikutuksen muut osapuolet eli suomea osaamattomat tutut ovat olleet oppijan roolissa. Tina kuvaa tilannetta positiiviseksi. Tuttavien innostus on ohjannut tilannetta eteenpäin.

Owen kirjoittaa, että hän toisinaan chattailee perheensä kanssa suomeksi huolimatta siitä, että nämä eivät osaa suomea. Kuva 3 on kuvakaappaus Owenin keskustelusta isänsä ja veljensä kanssa (sotkettu kohta on Owenin oma lisäys).

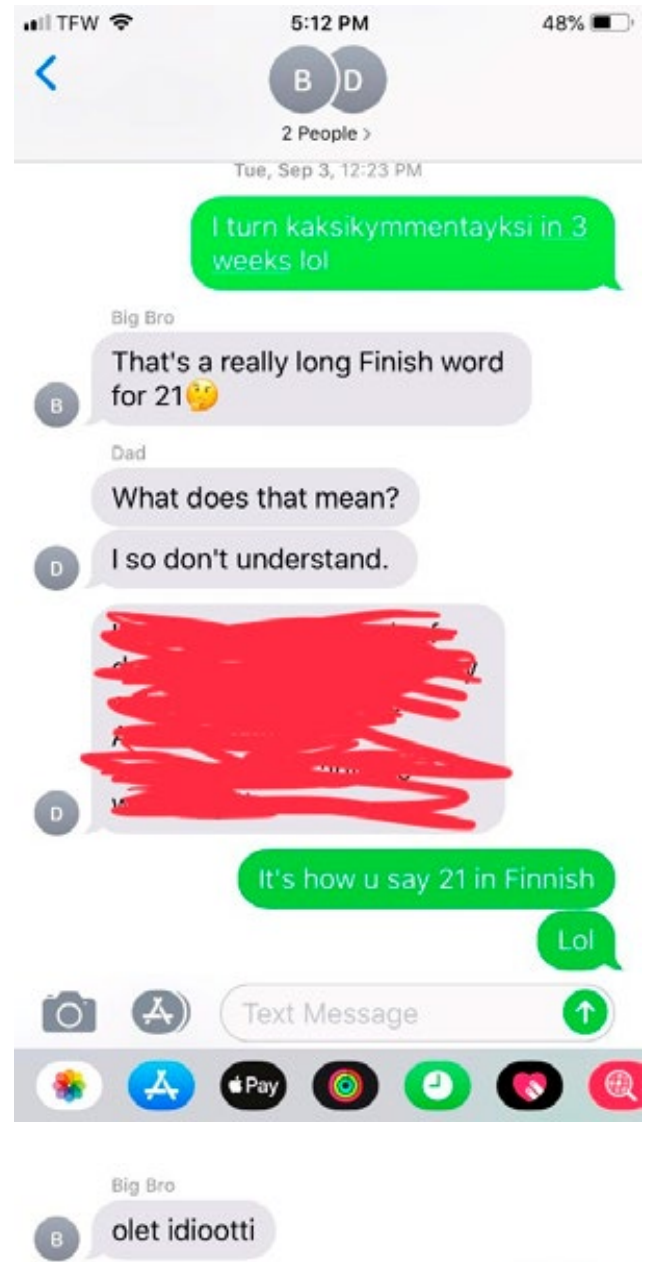

Kiitos!

Dad

D You are both huono!

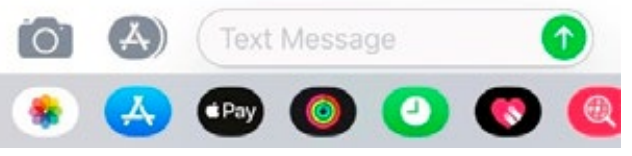

KUVA 3. Owenin perheen chat. 
Owen hyödyntää perheen chattia suomen kielen harjoitteluun ja opettaa chatissa numeron suomeksi. Owen on postannut chattiin kaksikielisen lauseen, jossa ainoastaan numero on suomen kielellä. $\mathrm{Lol}^{3}$-lyhenne kategorioi viestin huumoriksi, vastuuttaen muita osallistujia reagoimaan siihen (ks. Enfield \& Sidnell, 2017, s. 525). Veljen vastaus ja pohtiva emoji osoittavat, että hän on mahdollisesti kontekstista päätellyt sanan kaksikymmentäyksi merkityksen ja myös sanan pituuden tuoman humoristisen lisän lauseeseen. Isä puolestaan vastaa viestiin pyytämällä tarkennusta, jolloin Owen joutuu määrittelemään viestin merkityksen eksplisiittisemmin. Isoveli jatkaa suomenkielistä huumoria kirjoittamalla: olet idiootti. Owenin vastaus, kiitos, on merkitykseltään kontrastissa isoveljen syytöksen kanssa, ja oletuksen vastainen reaktio jatkaa huumorin rakentamista. Isäkin osallistuu kaksikieliseen huumoriin toteamalla: You are both huono! Vuorovaikutustilanne toimii kielen työstämisen ympäristönä (van Lier, 1996, s. 54). Näyttää siltä, että suomen kieli toimii perheen yhteisen huumorin rakentajana.

Esimerkeissä oppijan asema muuttuu. Hän ei olekaan enää vain suomen kielen oppija vaan myös sen asiantuntija ja opettaja. Suomen kieltä jakaessaan oppijat saavat myös itse harjoitusta. Asioitahan yleisen käsityksen mukaan oppii parhaiten opettamalla niitä itse muille. Suomen kieli näyttäytyy muidenkin opiskelijoiden portfolioissa tietynlaisena erikoisuutena ja ylpeyden aiheena, jota he mielellään jakavat. Esimerkiksi Owen kirjoittaa: "Finnish is definitely a lesser known language here in America, so my friends think it is really exciting when I can speak some of it to them." Suomen kielen opiskelun myötä hän on saavuttanut erityisasiantuntijuuden, josta muut ovat kiinnostuneita ja haluavat osallisiksi. Näissä esimerkeissä tulee esille vieraan

3 Lol = "laughing out loud" (Oxford English Dictionary, 2021) kielen oppimiskontekstin erityislaatuisuus suhteessa immersioympäristöön: kohdekielisessä ympäristössä oppijoille harvemmin tarjoutuisi vastaavanlaisia mahdollisuuksia kieliasiantuntijuuteen, koska kielen tuntijoita on paljon. Suomen kielen taito on vieraan kielen kontekstissa keino erottautua, mikä taas motivoi oppimaan. Jo kehittyvällä kielitaidolla voi olla kieliasiantuntija ja opettaa alkeita muille kiinnostuneille.

\section{POHDINTA}

Tässä artikkelissa tarkastelin vuorovaikutusjärjestystä ja toimijuutta amerikkalaisten suomenoppijoiden itsenäisen kielenkäytön portfolioissa. Portfolioista esiin nousivat oppijan oman aloitteellisen toimijuuden merkitys ja vuorovaikutusjärjestyksen hierarkkisuus, joka syntyi oppijan tarpeesta saada vuorovaikutuskumppanista ja -tilanteesta maksimaalinen hyöty ja oppijan ja asiantuntevan suomen puhujan erilaisiksi koetuista resursseista ja rooleista. Vuorovaikutustilanteessa oppija aktiivisesti altisti itseään kohdekielelle ohjaten tilanteen kulkua aloitteellisuudellaan ja kysymyksillään. Asiantuntevan kielenkäyttäjän puhe toimi kohdekielisen altistuksen ja oppimisen tarjoumana. Vuorovaikutus rakentuikin usein oppijan aloitteen ja asiantuntevan kielenkäyttäjän reaktioiden varaan. Toisaalta aineistossa näkyi myös oppijan pyrkimys tasaveroisempaan vuorovaikutukseen. Roolit myös kääntyivät niin, että oppija toimi itse kieliasiantuntijana kieltä vielä osaamattomien tuttaviensa keskuudessa.

Tutkimuksen suomenoppijat osallistuvat monenlaisiin vuorovaikutustilanteisiin sekä kasvokkain että teknologiavälitteisesti. Osa kielenkäyttömahdollisuuksista vaikuttaa luonteeltaan "yllättävän tilanteen haltuun ottamiselta”, kun taas osassa näkyy valmistautuminen, tavoitteellisuus ja kriittinen pohdinta. Keskiössä näyttää olevan ylipäätään mahdollisuus suomenkielisiin viestintätilan- 
teisiin. Portfolioissa näkyi väläyksiä amerikkalaisten suomenoppijoiden kielikäsityksestä. Kielenkäytön "täydellisyys" ei ollut oppijoille pääasia, vaan viestinnän onnistuminen ja ymmärretyksi tuleminen.

Globaalissa maailmassa vieraan kielen pedagogiikka on uudenlaisten kysymysten äärellä (ks. myös Kramsch, 2014). Luokassa ja luokan ulkopuolella tapahtuva kielenkäyttö eivät välttämättä aina kohtaa oppimisessa (Dufva ym., 2003; peruskouluista Luukka ym., 2008). Toisen kielen oppimista koskevissa pedagogisissa keskusteluissa on jo pitkään pohdittu oppimateriaalin funktionaalisuuden merkitystä (esim. Aalto ym., 2009). Samaa ajattelua pitäisi tuoda myös vieraan kielen pedagogiikkaan ja pohtia sitä, millaisiin kielenkäyttötilanteisiin oppijoita tulisi valmentaa vai tulisiko oppijan kenties valita tilanteet itse. Oppikirjoissa usein esiintyvien arkisten asiointitilanteiden, kuten ruokakaupassa asioimisen tai lääkärissä käymisen, hoitaminen suomeksi ei ole vieraan kielen oppijoille usein tarvehierarkiassa ensisijaista, sillä he eivät asu Suomessa tai välttämättä suunnittele sinne muuttoa, ja tilanteiden harjoittelukin voi tuntua keinotekoiselta. Vieraan kielen oppijat saattavat sen sijaan käyttää kieltä verkostojen ja yhteyksien ylläpitämiseen teknologiavälitteisesti ja omassa elinympäristössä sieltä poistumatta. Koko oma elinympäristö voi olla kielenoppijan temmellyskenttää ja täynnä kielenkäytön tarjoumia, myös vieraan kielen oppimisen kontekstissa. Kielellä on tärkeä rooli esimerkiksi identiteetin rakentamisessa sekä yhteisöllisyyden muodostamisessa. Oppijat itse voivat olla aktiivisia kohdekielen käyttötilanteiden etsimisessä ja niiden havainnoimisessa.

Yksi vieraan kielen opetuksen keskeisistä tavoitteista voisikin olla uudenlaisten viestintätapojen harjoitteleminen, erilaisten kontaktien rakentaminen sekä verkostoitumiseen kannustaminen. Opetuksella on tärkeä rooli oppijoiden varustamisessa parhailla mahdollisilla resursseilla oppimisympäristönsä tarjoumien hyödyntämiseen (Menezes, 2011, s. 71). Tärkeää on myös teknologioihin, kuten sosiaaliseen mediaan, tutustuminen, ja näissä viestimisen harjoittelu. Kielikursseilla toteutetut teknologiahankkeet voisivat olla kimmokkeena erilaisten medioiden haltuunottoon, yhteisöllisyyden rakentamiseen sekä teknologian ja verkostojen hyödyntämiseen itsenäisesti jatkossakin. Esimerkiksi tässä artikkelissa kuvatun portfoliotehtävän tavoitteena on ollut monipuoliseen kielenkäyttöön kannustaminen teknologiavälitteisesti ja omassa toimintaympäristössä.

Vieraan kielen kontekstissa toimijuutta on aiemminkin tutkittu erityisesti englanti vieraana kielenä (EFL) -tutkimuksen näkökulmasta luokkahuoneopetuksen kontekstissa (ks. esim. Kalaja, Ferreira, Aro \& RuohotieLyhty, 2015). Muiden kielten osalta toimijuutta on tarkasteltu vähemmän erityisesti opiskelijoiden itsensä valitsemissa arjen tilanteissa. Toimijuuden tarkastelu näissä tilanteissa on kuitenkin tärkeää, koska tilanteet heijastelevat oppijoiden arkea luokkahuoneen ulkopuolella. Tutkimukseni tarjoaakin lisää näkökulmia siihen, millaisissa tilanteissa opiskelijat kohdekieltä käyttävät.

Tässä tutkimuksessa viitekehyksenä toimi ekologinen lähestymistapa kielenoppimiseen ja tutkimusprosessina sekä -menetelmänä neksusanalyysi. Neksusanalyyttinen tutkimusprosessi soveltui monipuolisessa ja kompleksisessa tutkimusaineistossa navigoimiseen, koska menetelmä mahdollisti tutkimusongelman tarkastelun läheltä vuorovaikutuksen tasolla ja kauempaa tilanteisena toimintana sekä erilaisten yhteyksien havainnoimisen. Ekologinen lähestymistapa käsittää yksilön suhteessa ympäristöönsä, ja tämän dynamiikan ja verkottuneisuuden kartoittamiseen neksusanalyysi soveltui erinomaisesti. Artikkelissa keskityin erityisesti vuorovaikutus- 
järjestyksen käsitteeseen mutta tarkastelin myös soveltuvin osin paikan diskursseja ja toimijahistorian käsitettä. Mikrotason analyysimenetelmänä käytin diskurssianalyysia, joka soveltui hyvin vuorovaikutusjärjestyksen tarkasteluun. Neksusanalyysi kaipaa rinnalleen tällaista tarkemman analyysin välinettä.

Neksusanalyysiin kuuluu paitsi toiminnan tutkiminen myös sen muuttaminen. Tutkimuksen aineistonkeruussa hyödynnetty portfoliotehtävä on yksi yritys valjastaa oppijoiden

\section{LÄHTEET}

Aalto, E., Mustonen, S. \& Tukia, K. (2009). Funktionaalisuus toisen kielen opetuksen lähtökohtana. Virittäjä, 113, 402-423. Saatavissa: https://journal.fi/virittaja/article/ view/4204 [Viitattu 3.5.2021.]

Alanen, R. (2000). Vygotsky, van Lier ja kielenoppiminen: Sosiokulttuurinen viitekehys kielellisen tietoisuuden ja vieraan kielen oppimisen tutkimuksessa. Teoksessa P. Kalaja \& L. Nieminen (toim.), Kielikoulussa - kieli koulussa. AFinLA n vuosikirja 58, (s. 95-120). Jyväskylä: Suomen soveltavan kielitieteen yhdistyksen julkaisuja. Saatavissa: https://journal.fi/afinlavk/article/view/59844 [Viitattu 3.5.2021.]

Alm, A. (2015). "Facebook" for informal language learning: Perspectives from tertiary language students. The Eurocall Review, 2, 3-18. Saatavissa: https://polipapers.upv.es/ index.php/eurocall/article/view/4665/4791 [Viitattu 3.5.2021.]

Alvesson, M. (2003). Methodology for close up studies - struggling with closeness and closure. Higher Education, 46, 167-193. Saatavissa: https://doi.org/10.1023/A:1024716513774 [Viitattu 22.12.2020.]

Benson, P. (2001). Teaching and researching autonomy in language learning. Harlow: Longman.

Blommaert, J. (2010). Repertoires and competence. Teoksessa The sociolinguistics of globalization. Cambridge approaches to language contact, (s. 102-136). Cambridge: Cambridge University Press. itsenäistä kielenkäyttöä osaksi kurssioppimista. On kuitenkin tarve kehittää lisää malleja, joilla vahvistetaan ja tuetaan oppijoiden toimijuutta toimintaympäristössään. Lisäksi on tärkeää kohdentaa vieraan kielen opetuksen sisältöjä vastaamaan oppijoiden todellisia kielenkäyttötarpeita. Jatkossa tutkin vielä tarkemmin teknologiavälitteisen vuorovaikutuksen synnyttämiä tarjoumia ja kehitän tässäkin artikkelissa tarkastelun kohteena olleen suomen kielen ohjelman opetusta.

Dufva, H., Heikkilä, H. \& Martin, M. (2003). Koulun kahlitsemat - arjen selviytyjät: näkökulmia kielen oppimiseen. Teoksessa Koskela, M. \& N. Pilke (toim.), Kieli ja asiantuntijuus. AFinLAn vuosikirja 61, (s. 317-335). Jyväskylä: Suomen soveltavan kielitieteen yhdistyksen julkaisuja. Saatavissa: https://urn.fi/URN:NBN:fi:ELE-903130 [Viitattu 22.12.2020.]

Enfield, N. J. \& Sidnell, J. (2017). On the concept of action in the study of interaction. Discourse Studies, 19(5), 515-535. Saatavissa: https://doi. org/10.1177/1461445617730235 [Viitattu 3.5.2021.]

Goffman, E. (1983). The interaction order. American Sociological Review, 48, 1-17. Saatavissa: https://doi.org/10.2307/2095141 [Viitattu 3.5.2021.]

Hanks, J. (2017). Exploratory practice in language teaching. Puzzling about principles and practices. New York: Palgrave Maxmillan.

Hurd, S. (2008). Affect and strategy use in independent language learning. Teoksessa $S$. Hurd \& T. Lewis (toim.), Language learning strategies in independent settings. Second Language Acquisition 33, (s. 218-236). Bristol: Multilingual Matters.

Kalaja, P., Ferreira, A. M., Aro, M. \& RuohotieLyhty, M. (2015) (toim.). Beliefs, agency and identity in foreign language learning and teaching. New York: Palgrave Macmillan.

Karjalainen, A. (2012). Liikkuva ja muuttuva suomi. Diskursiivis-etnografinen tutkimus amerikansuomalaisten kielielämäkerroista. 
Jyväskylä studies in humanities 186. Jyväskylän yliopisto. Saatavissa: https://jyx.jyu.fi/ handle/123456789/40399 [Viitattu 3.5.2021.]

Kelly S. W. (2012). Incidental learning. Teoksessa N. M. Seel (toim.), Encyclopedia of the sciences of learning. Boston. Saatavissa: https://doi. org/10.1007/978-1-4419-1428-6_366 [Viitattu 30.4.2021.]

Kramsch, C. (2014). Teaching foreign languages in an era of globalization: Introduction. The Modern Language Journal, 1, 296-311. Saatavissa: http://www.jstor.org/ stable/43651759 [Viitattu 3.5.2021.]

Kukulska-Hulme, A. (2012). Language learning defined by time and place: A framework for next generation designs. Teoksessa J. E. DíazVera (toim.), Left to my own devices: Learner autonomy and Mobile Assisted Language Learning. Innovation and Leadership in English Language Teaching, 6. (s. 1-13). Bingley: Emerald Group Publishing,

Kuure, L., Riekki, M. \& Tumelius, R. (2018). Nexus analysis in the study of the changing field of language learning, language pedagogy and language teacher education. Teoksessa L. Haapanen, L. Kääntä \& L. Lehti (toim.), Diskurssintutkimuksen menetelmistä. On the methods in discourse studies. AFinLA-e (11), 71-92. Saatavissa: https://doi.org/10.30660/ afinla.69208 [Viitattu 22.12.2020.]

Kuure, L. (2011). Places for learning: Technologymediated language learning practices beyond the classroom. Teoksessa P. Benson \& H. Reinders (toim.), Beyond the language classroom, (s. 34-46). New York: Palgrave Macmillan.

Lehtonen, H. (2015). Tyylitellen: Nuorten kielelliset resurssitja kielen sosiaalinen indeksisyys monietnisessä Helsingissä. Väitöskirja. Helsingin yliopisto, suomen kielen, suomalais-ugrilaisten ja pohjoismaisten kielten ja kirjallisuuksien laitos. Saatavissa: https://helda.helsinki.fi/ handle/10138/155659 [Viitattu 3.5.2021.]

Leppänen, S., Vaarala, H. \& Taalas, P. (2019). Sosiaalinen media - mahdollisuuksia ja haasteita kielikoulutuspolitiikalle. Teoksessa T., Saarinen, P. Nuolijärvi, S. Pöyhönen \& T. Kangasveri (toim.), Kieli, koulutus, politiikka. Monipaikkaisia käytänteitä ja tulkintoja, (s.91120). Tampere: Vastapaino.
Lilja, N. \& Piirainen-Marsh, A. (2018). Connecting the language classroom and the wild: Reenactments of language use experiences. Applied Linguistics, 4, 594-623. Saatavissa: https://doi.org/10.1093/applin/amx045 [Viitattu 30.4.2021.]

Luukka, M-R., Pöyhönen, S., Huhta, A., Taalas, P., Tarnanen, M. \& Keränen, A. (2008). Maailma muuttuu, mitä tekee koulu? Äidinkielen ja vieraiden kielten tekstikäytänteet koulussa ja vapaa-ajalla. Jyväskylän yliopisto: Soveltavan kielentutkimuksen keskus. Saatavissa: https:// jyx.jyu.fi/handle/123456789/36607 [Viitattu 30.4.2021.]

Menezes, V. (2011). Affordances for language learning beyond the classroom. Teoksessa P. Benson \& H. Reinders (toim.), Beyond the language classroom, (s. 59-71). New York: Palgrave Macmillan.

Mercer, S. (2012). The complexity of learner agency. Apples - Journal of Applied Language Studies, 6, 41-59. Saatavissa: https://apples. journal.fi/article/view/97838 [Viitattu 30.4.2021.]

Mercer, S. (2011). Understanding learner agency as a complex dynamic system. System, 39, 427436. Saatavissa: https://doi.org/10.1016/j. system.2011.08.001 [Viitattu 30.4.2021.]

Norton, B. \& Toohey, K. (2001). Changing perspectives on good language learners. TESOL 2uarterly, 35, 307-322. Saatavissa: https://doi. org $/ 10.2307 / 3587650$ [Viitattu 20.12.2020.]

Oxford English Dictionary (2021). LOL. Haettu 30.4.2021 osoitteesta https://www.oed.com/ viewdictionaryentry/Entry/291168

Pietikäinen, S. \& Mäntynen, A. (2019). Uusi kurssi kohti diskurssia. Tampere: Vastapaino.

Pietikäinen, S. (2012). Kieli-ideologiat arjessa. Neksusanalyysi monikielisen inarinsaamenpuhujan kielielämäkerrassa. Virittäjä, 116, 410-442. Saatavissa: https:// journal.fi/virittaja/article/view/7162 [Viitattu 30.4.2021.]

Piirainen-Marsh, A. \& Tainio, L. (2007). Jäljittely vuorovaikutteisena keinona oppia toista kieltä videopelitilanteissa. Teoksessa O.-P Salo, T. Nikula \& P. Kalaja (toim.), Kieli oppimisessa - Language in Learning. AFinLAn vuosikirja 65, (s. 157-179). Jyväskylä: Suomen soveltavan kielitieteen yhdistyksen julkaisuja. Saatavissa: https://journal.fi/afinlavk/article/view/59970 [Viitattu 30.4.2021.] 
Rampton, B. (1995). Crossing: Language and ethnicity among adolescents. London: Longman.

Scollon, R. \& Scollon, S. B. K. (2004). Nexus analysis. Discourse and the emerging internet. New York: Routledge.

Strömmer, M. (2017). Mabdollisuuksien rajoissa. Neksusanalyysi suomen kielen oppimisesta siivoustyössä. Väitöskirja. Jyväskylä Studies in Humanities 336. Jyväskylän yliopisto. Saatavissa: https://jyx.jyu.fi/handle/123456789/56113 [Viitattu 30.4.2021.]

Suni, M. (2008). Toista kieltä vuorovaikutuksessa. Kielellisten resurssien jakaminen toisen kielen omaksumisen alkuvaiheessa. Väitöskirja. Jyväskylä Studies in Humanities 94. Jyväskylän yliopisto. Saatavissa: https://jyx.jyu.fi/ handle/123456789/18556 [Viitattu 4.4.2021.]

Vaarala, H. \& Jalkanen, J. (2011). Digitaaliset tekstit toisen kielen oppimisessa. Teoksessa E. Lehtinen, S. Aaltonen, M. Koskela, E. Nevasaari \& M. Skog-Södersved (toim.), Kielenkäyttö verkossa ja verkostoissa. Suomen soveltavan kielitieteen yhdistyksen julkaisuja 69, (s. 123138). Jyväskylä: Suomen soveltavan kielitieteen yhdistys AFinLA. Saatavissa: https://journal. fi/afinlavk/article/view/60031 [Viitattu 4.4.2021.]

van Lier, L. (2010). The ecology of language learning and sociocultural theory: Practice to theory, theory to practice. Procedia Social and Behavioral Sciences, 3, 2-6. Saatavissa: https://doi.org/10.1016/j.sbspro.2010.07.005 [Viitattu 4.4.2021.]

van Lier, L. (2004). The semiotics and ecology of language learning. Perception, voice, identity and democracy. Utbidning \& Demokrati, 3, 79-103.

van Lier, L. (2000). From input to affordance: Social interactive learning from an ecological perspective. Teoksessa J. P. Lantolf (toim.), Sociocultural theory and second language learning, (s. 245-59). Oxford: Oxford University Press.

van Lier, L. (1996). Interaction in the language curriculum. Awareness, autonomy and authenticity. Lontoo: Longman.
Virtanen, A. (2017). Toimijuutta toisella kielellä. Kansainvälisten sairaanhoitajaopiskelijoiden ammatillinen suomen kielen taito ja sen kehittyminen työharjoitteluissa. Väitöskirja. Jyväskylä Studies in Humanities (311). Jyväskylä University Press. Saatavissa: https://jyx.jyu.fi/ handle/123456789/53539 [Viitattu 3.4.2021.] VISK = Hakulinen, A., Vilkuna, M., Korhonen, R., Koivisto, V., Heinonen, T. R. \& Alho, I. (2004). Iso suomen kielioppi. Helsinki: Suomalaisen Kirjallisuuden Seura. Verkkoversio, viitattu 14.8.2021. Saatavissa: http://scripta.kotus.fi/ visk URN:ISBN:978-952-5446-35-7

Wagner, J. (2015). Designing for language learning in the wild: Creating social infrastructures for second language learning. Teoksessa $\mathrm{T}$. Cadierno \& S.W. Eskildsen (toim.), Usagebased perspectives on second language learning, (s. 75102). Berliini: Mouton de Gruyter. 


\section{AGENCY AND INTERACTION ORDER IN AMERICAN FINNISH LANGUAGE LEARNERS' INDEPENDENT TARGET LANGUAGE USE}

Elisa Räsänen, Indiana University \& University of Jyväskylä

This paper focuses on Finnish learners' independent target language use outside of class in an American university-level Finnish program that is geographically distant from any native speaker communities. Earlier research has demonstrated a mismatch between classroom and outside of class learning and use. In the global postmodern world foreign language students can use the target language in authentic situations already at the beginning of their studies in their learning environment, as this paper demonstrates. The study follows a nexus analytical method and an ecological approach to language learning to explore and analyze how four American learners of Finnish report and reflect on their language use. The data is excerpted from a portfolio assignment in which students have documented and reflected on their independent language use and it is analyzed using discourse analysis. Students' active agency and initiative had a significant role in the interactions. The interactions reported in the portfolios were hierarchically constructed following the different perceived roles of a language learner and an expert speaker. Students utilized their interlocutor to get maximal relevant exposure in the target language and the interaction event was often constructed around the learner's questions and expert speaker's answers. The results can be used to develop foreign language pedagogy to better correspond with learners' actual needs in the target language.

Keywords: agency, affordance, discourse analysis, foreign language learning, interaction order, nexus analysis, social media 
